\title{
DYNAMIC AND RESUSPENSION BY WAVES AND SEDIMENTATION PATTERN DEFINITION IN LOW ENERGY ENVIRONMENTS. GUAÍBA LAKE (BRAZIL)
}

\author{
João Luiz Nicolodi*, Elirio E. Toldo Jr. and Leandro Farina \\ Universidade Federal de Rio Grande - Instituto de Oceanografia - (FURG) \\ (Av. Itália, Km 8, s/n, Campus Carreiro, 96201-900 Rio Grande, RS, Brasil) \\ *Corresponding author: jl.nicolodi@bol.com.br
}

\begin{abstract}
A B S T R A C T
Little research has been undertaken into sediment dynamics in lakes, and most of it only analyses particular aspects such as the texture of the sediments. In this study, the characteristics of the wave field in Guaíba Lake are investigated. The parameters significant wave height (Hs), period (T) and direction of wave propagation are examined together with their relation to the resuspension of sediments at the bottom. For this purpose, the mathematical model SWAN (Simulating Waves Nearshore) has been validated and employed. The results pointed out that the highest waves modeled reached $0.55 \mathrm{~m}$ at a few points in the lake, particularly when winds were blowing from the S and SE quadrants with an intensity over 7 m.s-1. Generally speaking, waves follow wind intensity and direction patterns, and reach maximum height in about 1 to 2 hours after wind speed peaks. Whenever winds were stronger, waves took some 2 hours to reach $0.10 \mathrm{~m}$. However, with weak to moderate winds, the waves took around 3 hours to achieve this value in significant wave height. In addition to speed and direction, wind regularity proved relevant in generating and propagating waves on Lake Guaíba. In conclusion the lake's sediment environments were mapped and classified as follows: 1) Depositional Environments (51\% of the lake); 2) Transitional Environments (41\%); and 3) Erosional or Non-Depositional Environments (8\%). As a contribution to the region's environmental management, elements have been created relating to the concentration of suspended particulate matter.
\end{abstract}

\section{RESUMO}

Pesquisas referentes à dinâmica sedimentar em lagos são escassas e a maioria trata da distribuição e textura dos sedimentos, sendo raras aquelas que fazem menção ao padrão de ondas e suas relações com a ressuspensão destes sedimentos e suas consequências. Este trabalho analisa as características das ondas incidentes no Lago Guaíba (Brasil) por meio da utilização do SWAN (Simulating Waves Nearshore) e suas relações com a ressuspensão de sedimentos junto ao fundo. Os resultados mostraram que as maiores ondas incidentes atingiram $0.55 \mathrm{~m}$, particularmente quando de ventos do quadrante $\mathrm{S}$ e $\mathrm{SE}$ e com velocidades maiores que $7 \mathrm{~m} / \mathrm{s}$. Em termos gerais, as características das ondas seguem os padrões de intensidade e direção dos ventos, atingindo seus máximos valores aproximadamente 1 ou 2 horas após a velocidade de pico dos ventos. Em conclusão, os ambientes de sedimentação do lago foram mapeados e classificados da seguinte forma: 1) Ambientes Depositionais (51\% da área do lago); 2) Ambientes Transicionais (41\%); e 3) Ambientes Erosionais ou de não deposição (8\%).Como forma de contribuir à gestão ambiental da região, foram gerados subsídios referentes ao potencial de concentração de material particulado em suspensão.

Descriptors: Wave modeling, Sediment Environments, SWAN, Low energy environments, Resuspension by waves, Sedimentology.

Descritores: Ambientes sedimentares, Ambientes de baixa energia, Ressuspensão por ondas, Modelagem de ondas.

\section{INTRODUCTION}

Sheltered environments such as lakes and lagoons are especially to be recommended for the modeling of hydrodynamic patterns, since they show a low relative energy variation and can be considered as closed or semi-closed systems. Furthermore, the wind and waves tend to follow more regular patterns, allowing a better agreement between reality and the model's governing equations.

Let us review some of the works published in this context. Zeigler (1969) has already drawn attention to the high applicability of models in hydrodynamics studies, pointing out that, although most of them have been developed in marine environments, they fit perfectly well for studies of lakes and lagoons. Other important works are those of 
Resio and Hiipakka (1976) and Schwab et al. (1984), where numerical models were used to predict the wave spectrum, wave height, direction and period in the Great Lakes region. On the other hand, Nummedal et al. (1984) and Liu (1987) have experimented with several wave models on Lake Erie (Pennsylvania, USA). They confirm, based on their analysis of the wave spectra, that the models perform positively when applied to environments with limited and variable fetch.

Some other very important variables for the study of lake dynamics are the specific physical and chemical properties of fine sediments that tend to attract certain contaminants. These sediments can be carrying agents that remove water contaminants. Once deposited, sediments contaminated with heavy metals that are slow to degrade may become a source of contaminants waiting for extreme events or human activity to be remobilized and return to the food chain (MARTIN; MCCUTCHEON, 1999).

In order to define the degree of impact this kind of sediment has in a body of water, the main parameters to be analyzed are the wave climate, bathymetry and geomorphology. This study uses mathematical modeling techniques to predict waves (using the SWAN model), in addition to the tools available in the Geographic Information Systems (GIS). The purpose is to describe Lake Guaíba's wave patterns, both in terms of time and space, identifying the places more subject to wave action and/or prone to lakebed sediment resuspension. To this end, the following parameters: significant wave height, direction of wave propagation, average and peak wave period, and orbital motion near the lakebed, were analyzed.

\section{The Lake's Dynamics}

Lake Guaíba (which in the Tupy-Guarany language means bay of all waters) is set in the lowlands between the edge of the Crystal Shield and the Rio Grande do Sul Coastal Plains and covers an area of $496 \mathrm{~km}^{2}$. The Lake receives the outflow of eight sub-basins stretching out through the center and northeast of Rio Grande do Sul state and which cover an area of $84,763.5 \mathrm{~km}^{2}$, including more than 250 municipalities. This is the state's most densely populated region, with some 6.5 million inhabitants, who account for almost $70 \%$ of the state's GDP. This includes the state capital Porto Alegre, which uses water from the Lake for public supply (Fig. 1).

The first studies on Guaíba sedimentation were conducted in the 1970's and describe the morphological, mineral, and textural features of the Lake. Roughly speaking, one may say that the area drained by the Rio Grande do Sul Southeast Basin, consisting of plutonic, volcanic and sedimentary rocks, forms the highlands, which accounts for the remarkable volume of sediments that are carried into the Guaíba, mainly by the Jacuí, Sinos, Taquari, and Gravataí Rivers (TOLDO JR., et al., 2000).

The outflow from the tributaries loses its carrying ability when it enters the wide depositional Guaíba basin, where coarse sediments are retained, giving rise to the Jacuí River Delta (Fig. 1). Fine sediment enters the lake as plumes of suspended material.

The intense sedimentation of Lake Guaíba can be measured by the long-term sedimentation rates recorded by Toldo Jr. et al. (2000), in the lagoonal basin, with an average volume of $0.52 \mathrm{~mm} /$ year. However, short-term sedimentation rates obtained by the $210 \mathrm{~Pb}$ method indicate values between 3.5 and 8.3 $\mathrm{mm} /$ year over the last 150 years (MARTINS et al., 1989), which reflects human activity, particularly farming, in areas influenced by the drainage basin.

Fine sediments are preferably deposited beyond the $3 \mathrm{~m}$ isobath. Between the shoreline and the $3 \mathrm{~m}$ isobath, the lakebed typically displays sandy sediment with no fine sediment above it (BACHI et al., 2000). This absence of fine sediment is to be explained by wave action which resuspends the sediment through turbulence caused in the water column, making particle destination also dependent on the action of currents and the extent of the turbulent flow.

The lagoonal hydrodynamic regime, of which Lake Guaíba is part, is complex both in highwater and dry seasons. The cause and effect relationship among the several factors that play a role in the Guaíba outflow, particularly the strong influence of winds, shows that the lake is not just an extension channel of its tributaries, but a kind of reservoir, closely linked to the Patos Lagoon (Fig. 1).

Lake Guaíba behaves like a reservoir in which the Itapuã section (Fig. 1) acts as a control reflecting upstream and downstream level conditions. Despite the predominance of the natural outflow direction (from Guaíba to Patos Lagoon), the Lake's waters are strongly affected by winds, which cause water impoundment and reversed flows when blowing from the south quadrant. Variation in level is the main force that generates currents in the Guaíba. Its complex dynamics are still little known, since there are only a few studies in existence written by researchers of the Federal University of Rio Grande do Sul, the Federal University of Rio Grande (MOLLER JR. et al., 2001; CASTELAO; MOLLER JR., 2003) and government entities connected with water management (DNAEE - the National Department of Water and Electric Energy; DMAE - the Municipal Department of Water and Sewage).

The daily oscillations of the Guaíba are caused by wind speed variations, and are relatively 
regular, while wind direction, the Coriolis Effect, and the tide level at Rio Grande (a city located near the Patos Lagoon estuary) are secondary factors that increase or decrease these oscillations. During the high-water season, level variations are less affected by wind speed. In normal or dry seasons, winds of about $7 \mathrm{~m} . \mathrm{s}^{-1}$ may produce oscillations of over $50 \mathrm{~cm}$.

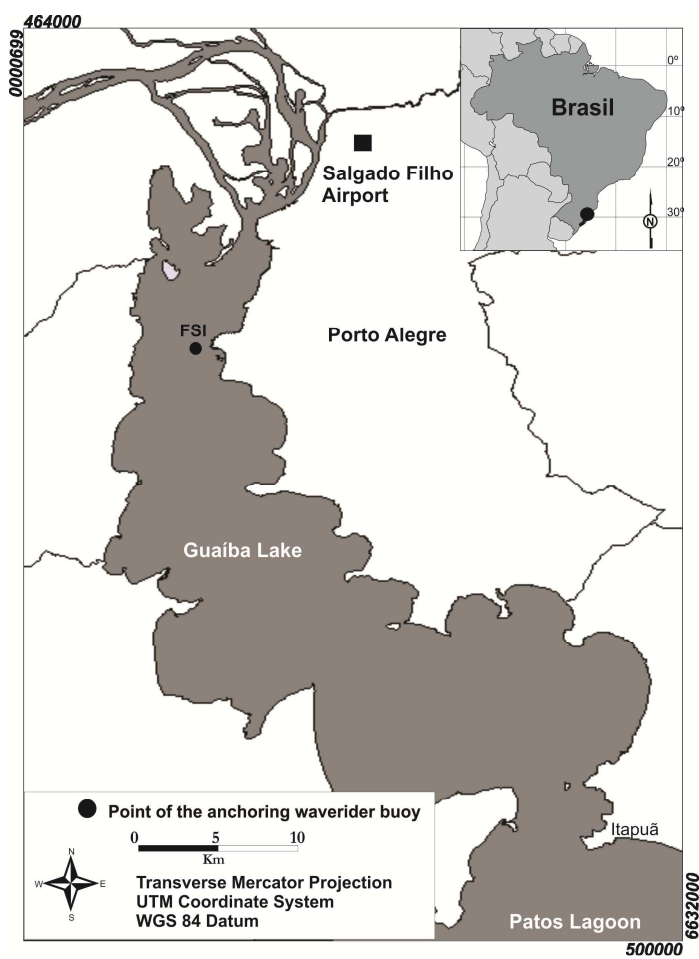

Fig. 1. Location map of Guaíba Lake, highlighting the region of Itapuã and Salgado Filho airport. The black dot "FSI" represents the location of the anchoring waverider buoy used to validate the wave model and current measurements.

\section{Material And Methods}

The following steps were taken for the analysis proposed in this study: a) preparation of a bathymetric model of the Lake; b) wind data analysis; c) mathematical wave modeling; d) analysis of the potential resuspension of sediments in the water column; e) relationship between the results and the points of the abstraction of water for human consumption in Porto Alegre.

\section{Preparation of a Bathymetric Model of the Lake}

This model has been created by compiling pre-existing data from the following sources: a) physical map from the Porto Alegre Environmental Atlas (MENEGAT et al., 1998); b) database of the «Sedimentation of the Guaíba River Complex» Project (BACHI et al., 2000), and c) data obtained from 14 topographic profiles developed for the Itapuã State Park beaches, located south of the Lake (NICOLODI; TOLDO JR., 2003).

Data interpolation was undertaken on SURFER 8.0 software with a $2 \mathrm{~m}$ spatial resolution, using the Kriging method, which is a locally adjusted statistical interpolator. The interpolations were made in small sectors scanned by quadrant, preferably in the NW-SE alignment, due to the Lake's direction and contour features.

This model was validated by comparison with interpolated profiles measured in the field with a recording ecobathymeter in the course of the «Mechanics of Lake Guaíba Currents» project undertaken by the National Department of Water and Electric Energy (DNAEE) in 1983. The methodology followed was that described by Plan et al. (2002), which had already been applied in Rio Grande do Sul in studies on shoreface delimitation on the Tramandaí continental platform - Rio Grande do Sul (GRUBER et al., 2006).

\section{Wind data Analysi}

As to local winds, twelve-month data relating to 1996 and 1997, obtained from Salgado Filho Airport (Fig. 1 ), measured daily at the standard height of $10 \mathrm{~m}$ at hourly intervals, were used.

The results can be seen in Figure 2, which shows the wind direction and speed data histogram. The data were transformed into 365-line, 24-column images, with each pixel equivalent to one hour's recording.

The predominant winds in the Porto Alegre region blew from the SE and $\mathrm{E}$ quadrants, according to $29 \%$ and $22 \%$ of the data recorded, followed by S, $\mathrm{NW}, \mathrm{N}$, and $\mathrm{W}$ winds, respectively, in $12 \%, 10 \%$, $8.8 \%$ and $7 \%$ of the records. The least frequent winds came from the NE and SW quadrants in $4.1 \%$ and $4.3 \%$ of the records analyzed. As to velocity, the average was $2.52 \mathrm{~m} . \mathrm{s}^{-1}$ and the maximum $13 \mathrm{~m} . \mathrm{s}^{-1}$. Calm atmospheric conditions and unrecorded data account for $13.7 \%$ of the data.

The statistical results of this data set were correlated with known weather standards for the Porto Alegre region (COUSSIRAT DE ARAÚJO, 1930; MORENO, 1961; LIVI, 1998; CAMARGO, 2002). The existing positive correlation between data sets permits the application of the results both in past situations and forecasts, since years 1996 and 1997 were considered «normal» with regard to the climate parameters used. 


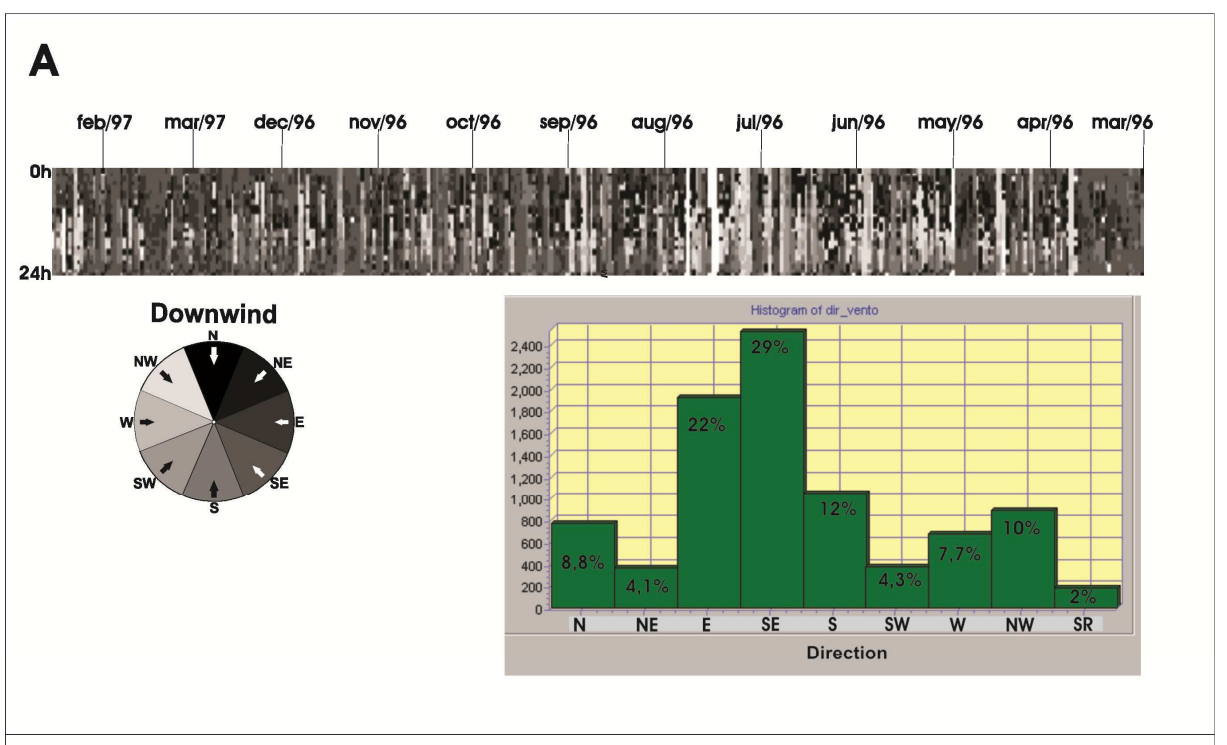

B

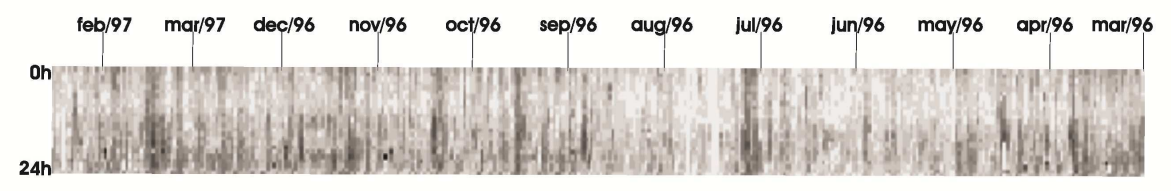

Velocity
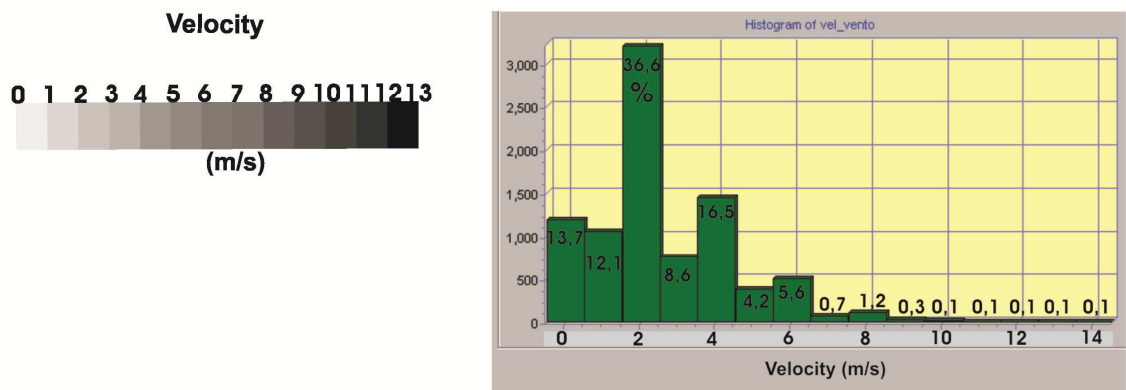

Fig. 2. Analysis of wind data: The figure 'A' represents the direction continuously over the period analyzed (record time) and the same data grouped into frequency histograms. Figure 'B' represents the velocity continuously over the period analyzed (record time) and the same data grouped into frequency histograms.

\section{Wave Modeling}

SWAN (Simulating Waves Nearshore) software was used for wave modeling. SWAN software is a numerical model for wave spectrum analyses in coastal zones, lakes and estuaries. Studies such as those by Lin et al. (1998) and Jin and Ji (2001) determined that SWAN, as compared with other models and data measured in the field, could be applied in sheltered environments (as, for example, Chesapeake Bay and Lake Okeechobee), with satisfactory results.
The model is based on an energy balance equation and follows the same methodology of third generation wave models as, for instance, WWATCH and WAM models (TOLMAN , 1997, 1999), but with more appropriate wave physics for shallow waters. SWAN describes waves through the action density spectrum $\mathrm{N}(\sigma, \theta)$ rather than the energy density spectrum $\mathrm{E}(\sigma, \theta)$, because action density is retained in the presence of currents, as opposed to energy density (WHITHAM, 1974 apud HOLTHUIJSEN, 2000), as per the equation 1 : 
$N(\sigma, \theta)=E(\sigma, \theta) / \sigma$

where $\sigma$ is the angular frequency, and $\boldsymbol{\theta}$ is the wave direction.

Besides wind and bathymetry data, other definitions were necessary for the use of SWAN:

- currents: the influence of currents on the wave climate was dismissed due to the low speeds observed. Bhowmik and Stall (1978) and Burrows and Hedges (1985) demonstrated that horizontal currents in shallow lakes significantly affect only wave height at speeds of over $0.5 \mathrm{~m} / \mathrm{s}$. In Lake Guaíba, currents have an average speed of $0.1 \mathrm{~m} / \mathrm{s}$ and a maximum speed of $0.15 \mathrm{~m} / \mathrm{s}$ (NICOLODI et al., 2010);

- water level -- as in the studies of Toldo et al. (2000), Wood et al (2001), Jin and Ji (2001), the level was considered constant for modeling purposes;

- water density $\left(1,000 \mathrm{~kg} / \mathrm{m}^{3}\right)$;

- $\quad$ spectrum domain - defined during the $0.3 \mathrm{~Hz}$ to 1 $\mathrm{Hz}$ interval to represent the highest possible number of waves.
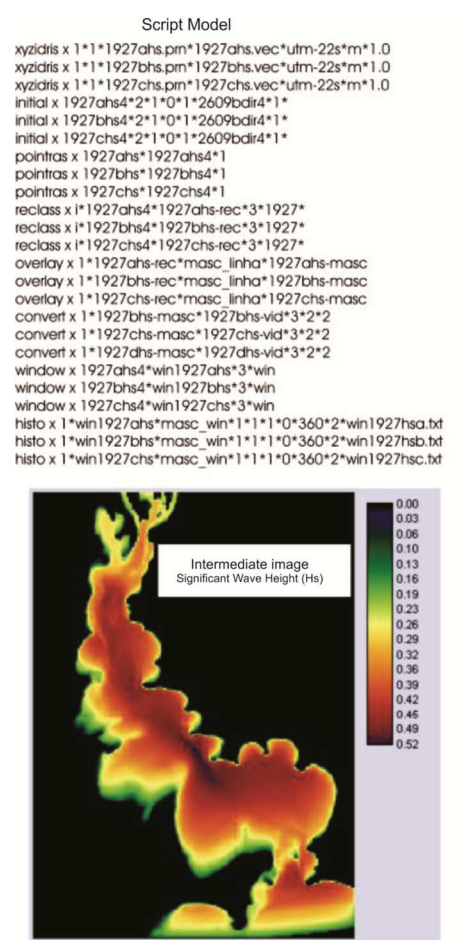

Fig. 3. Example of interaction between the SWAN model (data output in blocks of specific variables (Hs, T, dir) and Geographical Information System IDRISI through the use of script with the subroutine "macro modeller." This procedure imports the data from the SWAN, turning them into a point file and later into a raster image, leaving them ready for future crossings with any georeferenced variables.
Cartesian coordinates were used, as well as the Mercator projection system, and nautical convention for wind and wave directions. The spatial grid was composed of a rectangular grid with a $200 \mathrm{~m}$ resolution. The contours of Lake Guaíba (Jacuí River Delta and Patos Lagoon entrance) were considered closed.

Since SWAN assumes a static initial condition, it is initialized in a JONSWAP spectrum, calculated through wind speeds at $10 \mathrm{~m}$ from the interface between air and ocean. The application also uses the Kahma and Calkoen growth curve in deep waters (1992 apud Holthuijsen, 2000) and the significant height and peak spectrum frequency figures of Pierson and Moskowits (Holthuijsen, 2000).

The data generated by SWAN were analyzed in the IDRISI Geographic Information System through an automatic computer interface developed for this study. The combination of complex mathematical models such as SWAN and geoprocessing applications provides unique possibilities, since the gamut of tools available in these applications is immense, and allows cross-referencing data obtained from the model and any kind of data having the georeferenced spatial variable. An example of this interaction can be observed in Figure 3.
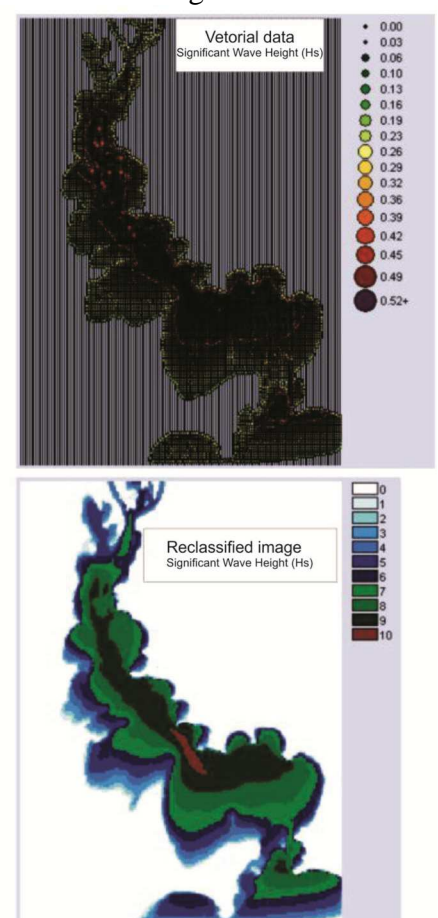


\section{RESUlTS AND Discussion}

The wave model was validated through a correlation of the data obtained with the data measured by an FSI3D waverider buoy produced by Falmouth Scientific, Inc., and moored near Jangadeiros Club, in the southern area of Porto Alegre (UTM 22S 474233 and 6667179) between June and August, 2005 (Fig. 1). The results were considered within expectations, and the correlation obtained was comparable to those of most of the studies consulted in the literature and deemed satisfactory (RIS et al., 1999; GORMAN; NEILSON, 1999; WOOD et al., 2001; SHAN-HWEIO et al., 2002; PIRES-SILVA et al, 2002; RUSU et al., 2002; OU et al, 2002; ROGERS et al., 2003, HSU et al., 2005; ZIJLEMA; WESTHUYSEN, 2005).

In addition to providing information on the wave climate and its relationship with the hydrodynamics and geomorphology of sheltered environments, lakes and ponds are also used for the calibration of the terms used in the formulation of the model itself. Westhuysen et al. (2007) carried out several tests with SWAN in two lakes in Holland (Lake Ijssel and Lake Sloten), for the purpose of assessing the whitecap term used in the model. This term was considered to be one of the causes of the unconformity found in the results of that period.

Most discrepancies occurred in the last few hours of monitoring, when winds abated as from 8 am on July 5 , and the original direction changed from the $\mathrm{S}$ to the W quadrant. At this point, the waves measured by FSI sharply decreased in height, which was not shown by the SWAN results, which posted a less abrupt height reduction. This indicates that SWAN tends to respond more slowly to fast wind directional variations, especially in sheltered environments such as the Guaíba, where waves depend entirely on wind energy. The same phenomenon was observed by Jin and Ji (2001) when using SWAN on Lake Okeechobee, in Florida. This kind of discrepancy can be attributed to nonlinear (triad or quadruplet) interactions between waves (Fig. 4).

With a view to determining the patterns of waves incident on Guaíba, we selected a few intervals in the series of wind data that stood out as the most intense situations and that also presented some regularity in the direction of provenance. Moreover, a range that represented the average wind conditions was selected. Figure 5 illustrates the significant height analyzed in one of the selected intervals (23rd and 24th, March 1996).

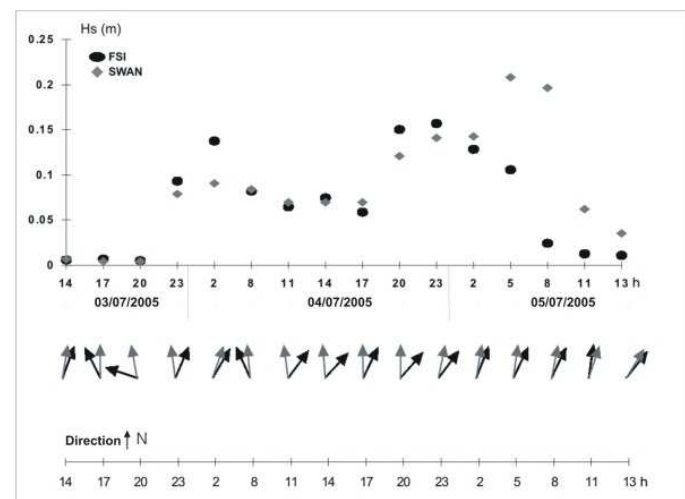

Fig. 4. Chart comparing data from significant height $(\mathrm{Hs})$ and wave direction measured by the waverider (in black) and the data obtained through the SWAN (in gray) during the validation of data. The localization of waverider can be seen in Figure 1.

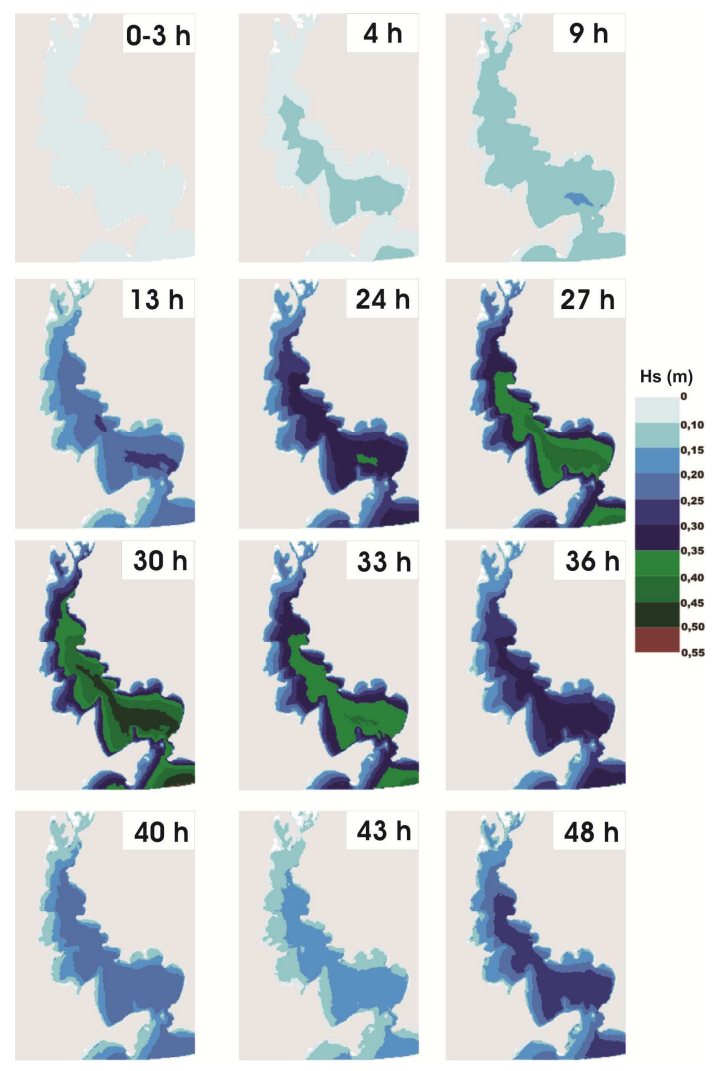

Fig. 5. Results regarding the significant wave height $(\mathrm{Hs})$ modeled for 48 hours between the 23th and 24th, March 1996 at Guaíba Lake. 
The wind speed during this period ranged from 2 to $10 \mathrm{~m} / \mathrm{s}$. In the first six hours, the direction of origin varied between the NW, N and W quadrants. At $7 \mathrm{am}$ the wind stabilized its direction in the NW quadrant, varying only at $7 \mathrm{am}$ on the 24 th. The waves accompanied, in general, the wind patterns.

The wave height varied between 0.05 and $0.45 \mathrm{~m}$ with the increase directly related to wind speed, reaching maximum values between 5 and 6 am on the $24^{\text {th }}$, approximately $2 \mathrm{~h}$ after the wind peak had occurred between 2 and 4 am. The waves started to decline after the decrease in wind intensity.

As from $18 \mathrm{~h}$ on the 24 th the wind blew with greater intensity $(8 \mathrm{~m} / \mathrm{s})$, which was again reflected in an increase in wave height. The curve of the period also followed the variations of wind speed, though less closely. The period values ranged from approximately $0.8 \mathrm{~s}$ to $1.8 \mathrm{~s}$. The direction of wave propagation was the main variable reflecting the changes in the wind. For the first 6 hours, during the period of change in the direction of the wind, the waves propagated predominantly from the NW, and between 5 and 6 hours, they began to migrate to the N. From 8am their direction stabilized again from the NW.

Under a northwesterly wind, recorded at 10 $\mathrm{h}, 20 \mathrm{~h}, 06 \mathrm{~h}$ and $16 \mathrm{~h}$, westward spreading waves were generated on the beaches of the east bank of the Guaíba, while on the west bank northerly waves were concentrated. The same situation was observed under a westerly wind, regarding the wave propagation at $6 \mathrm{~h}$.

This phenomenon is due to two main factors. The first concerns the flow direction of Lake Guaiba that follows the lake's general NW-SE alignment. The second relates to the process of wave refraction, characterized by the change in the direction of propagation due to the reduction in depth. It is this that causes an alignment of the surf zone such that the wave crests tend to be parallel to the shoreline.

In general, one can say that the waves on the Guaíba follow wind intensity and direction patterns, and attain maximum values about 1 or 2 hours after wind speeds peak. Under more intense winds, waves took about 2 hours to reach $0.10 \mathrm{~m}$, and wind direction did not remain constant at all times. With weaker winds, these times virtually doubled. Both situations with shorter response times coincided with those when wind intensity was less than $4 \mathrm{~m} / \mathrm{s}$. Wave increase was higher with wind speeds above $7 \mathrm{~m} / \mathrm{s}$.

In addition, a saturated wave spectrum was identified in Lake Guaíba by a numerical experiment. A situation was simulated in which winds blew steadily for 8 hours at speeds higher than $25 \mathrm{~m} / \mathrm{s}$. In this case, the highest wave increase $(0.55 \mathrm{~m})$ did not reflect the strong wind intensity. In addition to speed and direction, another factor that proved relevant in generating and propagating gravity waves on the
Guaíba was wind regularity. In situations when the wind blew constantly, waves tended to be higher.

The identification of wave patterns includes Lake Guaíba's general NW-SE orientation, which favors wave generation and propagation driven by certain wind regimes, and the wave refraction process, which leads to an alignment of the wave breaking zone approximately parallel to the shoreline.

\section{Analysis of Sediment Resuspension Potential in the Water Column}

According to Iron and Zollmer (1990 apud LAYBAUER; BIDONE, 2001), contamination is largely caused by organic and inorganic matter carried by water, mostly together with suspended material. Depending on the hydrodynamic characteristics of the environment, fine particles (formed chiefly by organic matter, clay minerals, and $\mathrm{Fe}$ and $\mathrm{Mn}$ oxides/hydroxides) may decant and deposit in the sediment substrate. Therefore, places where fine sediments accumulate are perfect sites to record not just geological features, but also the history of occupation and contamination of a water basin.

The relation between wave energy and the start of bottom sediment motion is then a key component to be analyzed. This evaluation consists of two main procedures: a) orbital speed $\left(U_{m}\right)$ and b) shear stress $\left(\tau_{\mathrm{o}}\right)$. While significantly different from each other in terms of methodology, they have a common wave orbital motion parameter, which is determined from the height $(\mathrm{H})$ and period $(\mathrm{T})$ of the surface wave. In this manner, the wave effectiveness in starting sediment motion is a function of the orbital motion near the bottom and its frequency $(1 / \mathrm{T})$.

The wave orbital motion near the lakebed used in this study was provided by SWAN, which shows this variable inserted in the bottom friction formulation, which includes the JONSWAP empirical models (HASSELMANN et al., 1973), the Collins (1972) drag law model and the eddy viscosity model of Madsen et al. (1998).

The interaction between water and bottom surface involves friction forces that act within a boundary layer. In shallow water environments, this layer may occupy a significant portion of total depth, and under certain conditions the boundary layer may contain almost the entire water column, as in shallow waters where waves break.

The vertical and horizontal distribution of orbital motion is changed near the bottom due to the boundary layer structure. The thickness of this layer is defined as the distance from the bottom to the maximum speed value related to the free flow.

The area covered by the boundary layer has more energy in its dynamics, when compared with other natural systems, and this significantly affects 
resuspension and carriage of sediments. It is therefore a modeling agent of shallow water topography (SWIFT et al. apud TOLDO et al., 2000).

Calculations were made to define the percentage of time for wave orbital motion to reach the minimum limit to start moving silt and very fine sand $\left(15 \mathrm{~cm} \cdot \mathrm{s}^{-1}\right)$ fractions of sediment by crosschecking information on wind frequency as a consequence of speed intervals and directions with the results relative to orbital motion $\left(U_{m}\right)$.

Based on the systematized information on sedimentary distribution, which are typical of incident waves, orbital motion, boundary layer, and the beginning of a turbulent flow, three sedimentation environments have been distinguished in Lake Guaíba (Fig. 6). The environments identified as (1) Depositional Environment, (2) Transitional Environment and (3) Erosional Environment have a spatial distribution largely determined by the Lake's geometry and bathymetry.

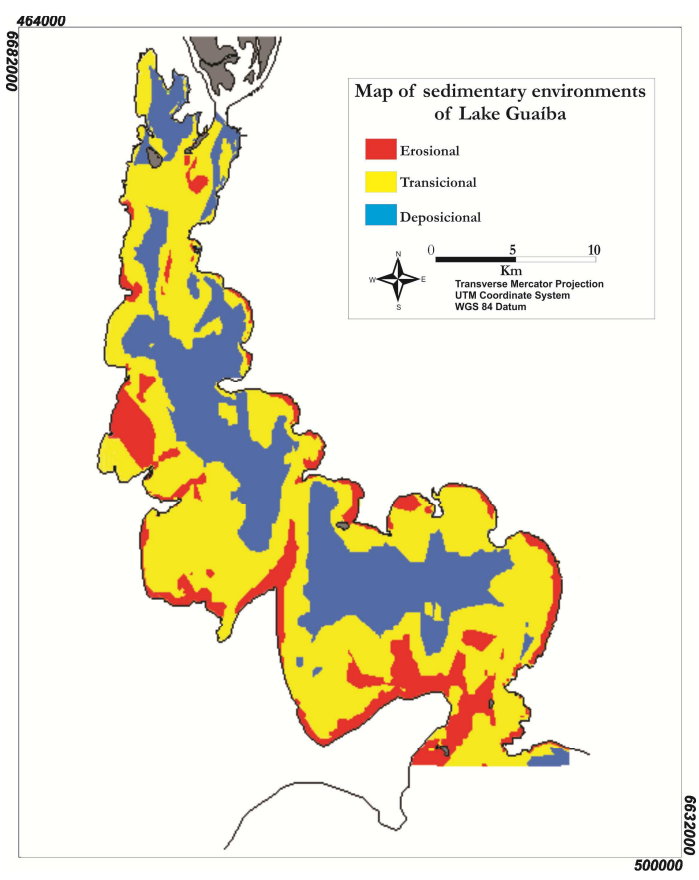

Fig. 6. Map of sedimentary environments of Lake Guaíba based on the systematized information on sedimentary distribution, which are typical of incident waves, orbital motion, boundary layer, and the beginning of a turbulent flow.

Depositional Environment: this corresponds to $51 \%$ of the lake's area. These are low hydrodynamic environments which favors the deposition of fine sediments. These deposits are located in deeper lake areas, near the navigation channel, and are sheltered from the main resuspension forces, which can be generated by wind waves from the $\mathrm{E}$ and $\mathrm{SE}$ quadrants, and currents induced by winds and discharge.

Transitional Environment: this corresponds to $41 \%$ of the lake's area. These are mostly low energy environments, their substrate consisting basically of sand and silt, remobilized in certain situations related to waves generated by winds of $11 \mathrm{~m} \cdot \mathrm{s}^{-1}$ or above. Under weaker wind conditions, erosion may occur in shallow areas. The spatial distribution of these areas occurs between the depositional and erosional environments, reflecting the transition between low and high energy regimes.

Erosional Environment: this corresponds to $8 \%$ of the lake's area. These are environments where erosion or non-deposition of fine sediments prevails due to wave action with orbital motion above $15 \mathrm{~cm} . \mathrm{s}^{-}$ ${ }^{1}$ for at least $50 \%$ of the time. A characteristic of these environments is a lakebed consisting of sand, since fine sediments are constantly remobilized and taken up into the water column. During periods without incident waves, depositions may occur on this kind of lakebed, to be once again remobilized by subsequent turbulence.

\section{Conclusions}

The Lake Guaíba wave climate was modeled for the years 1996 and 1997. This allowed the calculation of such parameters as the significant wave height, direction of wave propagation, average and peak wave periods, and orbital motion. Based on this information, maps of potential sediment resuspension and sedimentation environments on the Guaíba have been produced.

As a general rule, waves followed wind intensity and direction patterns, and reached maximum values between 1 and 2 hours after the wind speed peak. Whenever winds blew more intensely in the first hours, waves responded in about 2 hours to reach 0.10 $\mathrm{m}$. Wave increase was greater with wind speeds above $7 \mathrm{~m} \cdot \mathrm{s}^{-1}$.

Factors such as the lake's geometry and geomorphology were also important, particularly when there were sandy spits, which partly reduce wave energy, resulting in smaller wave heights, even in significant fetch situations.

One can say that that the Guaíba's waves can potentially generate near-bottom turbulence in different situations. However, the maximum depth does not exceed $1.9 \mathrm{~m}$ for $\mathrm{S}$ quadrant winds and minimum speeds of $11 \mathrm{~m} \cdot \mathrm{s}^{-1}$. On the other hand, the boundary layer thickness where the turbulent flow begins has very low values of up to $1 \mathrm{~cm}$.

Shallow areas containing fine to very fine sand and silt may present excessive turbulence, and this turbulence involves the entire water column in some places. This condition results in erosion of the 
sediments deposited on the Guaíba lakebed, usually where depths are less than $1.5 \mathrm{~m}$. Deposition of material carried in the water column occurs when there is no turbulent flow, or when there is an insignificant flow near the bottom.

Based on the information system on sedimentary distribution, typified by incident waves, orbital motion, boundary layer, and the beginning of a turbulent flow, three sedimentation environments have been defined in Lake Guaíba: 1) Depositional Environment; 2) Transitional Environment; and 3) Erosional or Non-Depositional Environment.

The Guaíba may be said to be a major receiver of sediments, since the bottom surface with deposition is much more extensive than the bottom surface with erosion. Besides, erosion, of which resuspension processes are the principal cause, is limited by low height and low frequency waves.

The results discussed in this paper have a direct relationship with the sedimentary patterns of Lake Guaíba. Further, they together form an intricate system in which causes and effects are often interwoven: bathymetry is a fundamental factor for the entire system, as it defines wave patterns, but at the same time it is defined by wave action, among other factors. The sedimentation environments identified are a result of this process, which makes them a source of information for the management of lagoonal environments such as, for example, those related to mining, the building of harbors, and, still more importantly, water quality.

All this technical information has a direct relationship to the quality of the water that is diverted to treatment plants in the region of Porto Alegre. The knowledge of hydrodynamics and the morphology of lakes is a basic prerequisite for watershed management since the action of waves on the surface layer of lakes and on their beds can trigger the re-suspension of sediments and the reintroduction of pollutants into the water column.

The results of this study can be used as useful information for other studies that call for knowledge of the dynamics of lake waves and their consequences for the sedimentary distribution and energy flows associated with this body of water.

\section{ACKNOWLEDGEMENTS}

We are grateful to the National Council for Scientific and Technological Development (CNPq) for providing a $\mathrm{PhD}$ scholarship during the course of this project.

\section{REFERENCES}

BACHI, F. A.; BARBOZA, E. G.; TOLDO JR, E. E. Estudo da sedimentação do Guaíba. Ecos, v. 17, p. 32-35, 2000.
BHOWMIK, N. G.; STALL, J. B. Circulation patterns in the Fox chain of lakes in Illinois. Wat. Resour.,v. 14, p. 633-642, 1978.

BURROWS, R.; HEDGES, T. S. The Influence of currents on ocean wave climates. Coast. Eng., v. 9, p. 247-260, 1985.

CAMARGO O. A. Atlas Eólico: Rio Grande do Sul. 2002. Porto Alegre: SEMC - Secretaria de Energia Minas e Comunicações, $2002.70 \mathrm{p}$.

CASTELÃO, R. M.; MÖLLER JR., O. O. Sobre a circulação tridimensional forçada por ventos na Lagoa dos Patos. Atlântica, v. 25, n. 2, p. 91-106, 2003.

COLLINS, J. I. Prediction of shallow water spectra. J. Geophys. Res., v. 77, n. 15, p. 2693-2707, 1972.

COUSSIRAT DE ARAÚJO, L. Memória sobre o clima do Rio Grande do Sul. Rio de Janeiro: Ministério da Agricultura, Indústria e Comércio, 1930. 38 p.

GORMAN, R. M.; NEILSON, C. G. Modelling shallow water wave generation and transformation in an intertidal estuary. Coast. Eng., v. 36, p. 197-217, 1999.

GRUBER, N. L. S.; TOLDO JR.; E. E.; BARBOZA, E. G.; NICOLODI, J. L.; AYUP-ZOUAIN, R. N. A shoreface morphodynamic zonation and the equilibrium profile von the Northern Coastline of Rio Grande do Sul, Brazil. J. Coast. Res, v. SI39, p. 504-508, 2006.

HASSELMANN, K.; BARNETT, T. P.; BOUWS, E.; CARLSON, H.; CARTWRIGHT, D. E.; ENKE, K.; EWING, J. A.; GIENAPP, H. Measurements of wind-wave growth and swell decay during the Joint North Sea Wave Project (JONSWAP). Deut. Hydrogr. Suppl., v. 8, p. 1-12, 1973.

HOLTHUIJSEN, L. H. SWAN - User manual. Delft: Department of Civil Engineering. Delft University of Technology. 2000. 124 p.

HSU, T. W.; OU, S. H; LIAU, J. M. Hindcasting nearshore wind waves using a FEM code for SWAN. Coast. Eng., v. 52 , p. 177-195, 2005

JIN, K. R.; JI, Z. G. Calibration and verification of a spectral wind - wave model for Lake Okeechobee. Ocean Eng., v. 28, p. 571-584, 2001.

LAYBAUER, L.; BIDONE, E. D. Caracterização textural dos sedimentos de fundo do Lago Guába e sua importância em diagnósticos ambientais. Pesquisa Geociênc., v. 28, p. 13-26, 2001.

LIN, W.; SANFORD, L.P.; ALLEVA, B.J.; SCHWAB, D.J. Surface wind wave modeling in Chesapeake Bay. In: INTERNATIONAL CONFERENCE ON OCEAN WAVE MEASUREMENT AND ANALYSIS, 3., 1998, Virginia. Anais... Virginia, 1998. p. 1048-1062.

LIU, P. C. Assessing wind wave spectrum representations in a shallow lake. Ocean Eng., v. 14, n. 1, p. 39-50, 1987.

LIVI, P. Elementos do clima: o contraste dos tempos frios e quentes. In: MENEGAT, R.; PORTO, M.L.; CARRARO, C. C.; FERNANDES, L. A. D.(Org.). Atlas Ambiental de Porto Alegre. Porto Alegre: Universidade Federal do Rio Grande do Sul, 1998. p. 177-184.

MADSEN, O. S.; POON, Y. K.; GRABER, H. C. Spectral wave attenuation by bottom friction: theory. In: INTERNATIONAL CONFERENCE ON COASTAL ENGINEERING, 21., 1998, New York. Anais... New York, 1998. v.1, p. 492-504.

MARTIN, J. L; MCCUTCHEON, S. C. Hydrodynamics and transport for water quality modeling. Ed. Lewis, 1999. $794 \mathrm{p}$. 
MARTINS, I. R.; VILLWOCK, J. L.; MARTINS, L. R.; BEMVENUTI, C.E. The Lagoa dos Patos estuarine ecosystem (RS, Brazil). Pesquisa Geociênc., v. 22, p. 544, 1989.

MENEGAT, R.; PORTO, M. L.; CARRARO, C. C.; FERNANDES, L. A. D. Atlas ambiental de Porto Alegre. Porto Alegre: Universidade Federal do Rio Grande do Sul, 1998. 237 p.

MOLLER, O. O.; CASTAING, P.; SALOMON, J. C.; LAZURE, P. The influence of local and non local forcing effects on the subtidal circulation of Patos Lagoon. Estuaries, v. 24, n. 2, p. 275-289, 2001.

MORENO, J. A. Clima do Rio Grande do Sul. Porto Alegre: Diretoria de Terras e Colonização. Secretaria da Agricultura. 1961. 64 p.

NICOLODI, J. L.; TOLDO JR, E. Beach Morphodynamics: A tool for coastal habitat managers. A case study - Praia de Fora, Itapuã State Park, RS. Natureza \& Conservação, v. 1, p. 66-75, 2003.

NICOLODI, J. L.; TOLDO JR. E. E.; FARINA, L. Dinâmica e ressuspensão por ondas no Lago Guaíba e suas implicações nos locais de captação de água para abastecimento humano. Pesquisa Geociênc., v. 37, p. 47-61, 2010.

NUMMEDAL, D.; SONNENFELD, D. L.; TAYLOR, K. Sediment transport and Morphology at the surf zone of Presque Isle, Lake Erie, Pennsylvania. Mar. Geol., v. 60, p. $99-122,1984$.

OU, S. H.; LIAU, J. M.; HSU, T. W.; TZANG, S. Y. Simulating typhoon waves by SWAN wave model in coastal waters of Taiwan. Ocean Eng.,v. 29, p. 947-971, 2002.

PLAN, N. G.; HOLLAND, K. T.; PULEO, J. A. Analysis of the scale of errors in nearshore bathymetric data. Mar. Geol., v. 191, p. 71-86, 2002.

PIRES-SILVA, A. A.; MAKARYNSKYY, O; MONBALIU, J.; VENTURA-SOARES, C.; COELHO, E.. Wam/Swan simulations in an open coast: Comparisons with ADCP Measurements. Littoral, The changing coast. EUROCOAST / EUCC, Porto-Portugal: EUROCOAST, 2002

RESIO, D. T.; HIIPAKKA, L. W. Great Lakes wave information. In: INTERNATIONAL CONFERENCE ON COASTAL ENGINEERING, 15.,1976. ASCE. Proc. ... ASCE, 1976. v. 1, p. 92-112.

RIS, R.C.; BOOIJ, N.; HOLTHUIJSEN, L. H. A thirdgeneration wave model for coastal regions. Part II: Verification. J. Geogr. Res., v. 104, n. C4, p. 7667 $7682,1999$.

ROGERS, W. E.; HWANG AND, P. A.; WANG, D. W. Investigation of wave growth and decay in the SWAN model: three regional-scale applications. J.Phys. Oceanogr., v. 33, p. 366-389, 2003.
RUSU, E.; VENTURA SOARES, C.; PIRES SILVA, A. PINTO, J. P.; MAKARYNSKYY. O. Near real time assessment of the wave propagation in the coastal environment of Portugal. Littoral, The changing coast. EUROCOAST / EUCC, Porto-Portugal: EUROCOAST, 2002

SCHWAB, D. J.; BENNETT, J. R.; LIU, P. C.; DONELAN, M. A. Application of a simple numerical wave prediction model to Lake Eire. J. Geophys. Res., v. 89, p. 35863592, 1984.

SHAN-HWEI, O.; JIAN-MING L.; HSU, T. W; SHIAWYIH T. Simulating typhoon waves by SWAN wave model in coastal waters of Taiwan. Ocean Eng., v. 29, p. 947-971, 2002

TOLDO JR, E. E.; DILLENBURG, S. R.; CORRÊA, I. C. S.; ALMEIDA, L. E. S. B. Holocene sedimentation in Lagoa dos Patos Lagoon, Rio Grande do Sul, Brazil. J. Coast. Res., v. 16, n. 3, p. 816-822, 2000.

TOLMAN, H. L. User manual and system documentation of WAVEWATCH-III version 1.15. NOAA/NWS/NCEP/OMB.: Technical Note 151, 1997. $97 \mathrm{p}$.

TOLMAN, H. L. User manual and system documentation of WAVEWATCH-III version 1.18 . NOAA/NWS/NCEP/OMB.: Technical Note 166, 1999. $110 \mathrm{p}$.

WESTHUYSEN, A. J. VAN DER.; ZIJLEMA, M.; BATTJES, J. A. Nonlinear saturation-based whitecapping dissipation in SWAN for deep and shallow water. Coast. Eng., v. 54, n. 2, p. 151-170, 2007.

WOOD, D. J.; MUTTRAY, M.; OUMERACI, H. The SWAN model used to study wave evolution in a flume. Ocean Eng., v. 28, p. 805-823, 2001.

ZEIGLER, J. M. Some observations and measurements of wind driven circulation in a shallow coastal lagoon. In: LAGUNAS COSTERAS, UN SIMPOSIO, 1., 1969, México, DF. Anais... UNAM - UNESCO, 1969. v. 1, p. 335-339.

ZIJLEMA, M.; WESTHUYSEN, A. J. VAN DER. On convergence behavior and numerical accuracy in stationary SWAN simulations of nearshore wind wave spectra. Coast. Eng., v. 52, p. 237-256, 2005.

(Manuscript received 13 July 2012; revised 12 February 2013; accepted 07 February 2013) 